\title{
EFFECTS OF MODIFYING SOIL MICROBES ON RESTORING VEGETATION DEGRADED BY AN INVASIVE PLANT CROFTON WEED (AGERATINA ADENOPHORA)
}

\author{
CHEN, L. ${ }^{1,2,3}-$ SHI, Y. T. ${ }^{1,3}-$ ZHANG, H. B. ${ }^{1,2,3 *}$ \\ ${ }^{I}$ State Key Laboratory for Conservation and Utilization of Bio-Resources in Yunnan, Yunnan \\ University, Kunming 650091, China \\ ${ }^{2}$ School of Ecology and Environmental Science, Yunnan University, Kunming 650091, China \\ ${ }^{3}$ School of Life Sciences, Yunnan University, Kunming 650091, China \\ *Corresponding author \\ e-mail: zhhb@ynu.edu.cn; phone: +86-871-6503-4282
}

(Received 22 ${ }^{\text {nd }}$ Aug 2019; accepted $25^{\text {th }}$ Nov 2019)

\begin{abstract}
Invasive plants commonly change soil microbial communities in their introduced range, promoting their own growth while inhibiting the growth of native species. This effect can persist even after invasive plants are removed, thereby hindering restoration of disturbed ecosystems. Our aim was to explore how modifying the altered soil microbe community affected the restoration of an area degraded by Ageratina adenophora (Crofton weed), one of the most notorious invasive plants in China. A threeyear experiment was performed in the wild. After the removal of A. adenophora, the three antimicrobial drugs Chlorothalonil (BJQ), Carbendazim (DJL), and Streptomycin (LMS) were applied to inhibit the activity of soil microbes. The reestablishment of A. adenophora and recovery of other plant species were investigated, and soil characteristics were evaluated. All three drugs significantly decreased the total biomass of reestablished A. adenophora: relative to the control, BJQ decreased A. adenophora biomass by $46.73 \%$, DJL by $70.69 \%$, and LMS by $96.95 \%$. Further, DJL and LMS significantly increased plant community diversity, as well as the biomass of other plant species. Drug treatment also significantly changed soil fertility and decreased soil enzyme activity. Our data indicated that inhibiting the activity of soil microbes is beneficial for both eradication and replacement of A. adenophora.
\end{abstract}

Keywords: plant community, antimicrobial drugs, interruption, environmental degradation, recovering, exotic species

\section{Introduction}

Invasive plants commonly change soil microbial communities in the introduced range to promote their own growth and inhibit the growth of native species (Klironomos, 2002; Callaway et al., 2004). To stimulate their own growth, invasive plants alter soil microbes such as mycorrhiza and nitrogen-fixing bacterial symbionts (positive feedbacks) (Richardson et al., 2000). However, invasive plants also inhibit the growth of native species (negative feedbacks) either indirectly by outgrowing and excluding native species in soils that lack soil pathogens in the novel range (i.e. enemy release) (Reinhart et al., 2005; Blumenthal et al., 2009), or directly by inhibiting beneficial microbe species that form mutualistic relationships with native plants (Vogelsang and Bever, 2009; Lankau, 2011). Moreover, some invasive plants can promote microbial species that are pathogenic to native plants in the rhizosphere of the soil (Mangla et al., 2008), referred to as the accumulating local pathogen (ALP) hypothesis (Eppinga et al., 2006). 
Restoring an ecosystem degraded by non-native plants is challenging and often unsuccessful, due in part to negative alterations to soil microbial communities that place native plants at a disadvantage (Hamman et al., 2013). This inability of ecosystems to recover from changes to the soil microbial community, referred to as the 'priority effect' (Grman and Suding, 2010) can persist even after non-native plants are removed (Marchante et al., 2009; Elgersma, 2011). Understanding priority effects is therefore essential for restoring degraded ecosystems because many native plants have been found to be especially vulnerable to such modifications (Kardol and Wardle, 2010). Further, eradication of a well-established invasive plant may result in the unexpected release of another, previously suppressed non-native species (Simberloff et al., 2013). For instance, Adler et al. (1998) demonstrated that the eradication of the invasive nitrogen-fixing species Myrica faya facilitated the invasion of other fast-growing nonnative grasses. Thus, insight into the role of a well-established invasive plant species in an ecosystem is important before eradication is attempted, as risk of invasion by other non-native species can remain high after the removal or reduction in the prevalence of an invader (Simberloff et al., 2013).

Ageratina adenophora (Crofton weed) is one of the most notorious invasive plants in China (Feng and Zhu, 2010; Wang et al., 2011). In the 1940s, Crofton weed began to colonize the Yunnan Province in southwestern China and from there it dispersed north and east at an average rate of $20 \mathrm{~km}$ per year (Sang et al., 2010). Although the spread of A. adenophora stopped in Yunnan after 1990, it is still rapidly expanding its distribution in neighboring provinces (Wang and Wang, 2006). Ageratina adenophora is known to cause acute asthma, diarrhea, depilation, and even death in livestock, as well as cause a decline in crop yields (Wang et al., 2017). The economic losses to animal husbandry and grassland ecosystem services caused by the weed has been estimated at RMB 0.99 billion and 2.63 billion per year, respectively (Wang et al., 2017). Of the multiple mechanisms hypothesized to promote the invasion of A. adenophora (Feng et al., 2007, 2009; Wang et al., 2011), changes to soil microbial communities in introduced areas may play an important role in aiding the spread of $A$. adenophora ( $\mathrm{Yu}, 2005)$. For example, Niu et al. (2007) demonstrated that A. adenophora invasion strongly increased both the abundance of soil vesicular-arbuscular mycorrhizal (VAM) fungi and the ratio of fungi to bacteria in soil, and that soil biota in a heavily invaded site had a greater inhibitory effect on native plant species than on A. adenophora. A. adenophora invasion has also been shown to significantly increase the amount and diversity of nitrogenfixing bacterial (NFB) in soils (Xu et al., 2012; Zhao et al., 2019). Chen et al. (2019) indicated that this weed can selectively enrich the soil rare bacteria as endophytes in roots.

Currently, mechanical or manual eradication techniques are used to prevent invasion of $A$. adenophora. One study reported that $A$. adenophora was a susceptible plant to herbicide tenuazonic acid (TeA) (Chen et al., 2015), suggesting TeA is a potential chemical control for $A$. adenophora invasion. In some cases, native species are planted following eradication of $A$. adenophora to restore the degraded area (Wang et al., 2008). However, these methods have not been very effective, as A. adenophora frequently becomes reestablished after several years of eradication (unpublished data). Such poor restoration efforts may reflect a failure to integrate current ecological knowledge from belowground microbiotas and aboveground vegetation. Although Elliott et al. (2015) reported that microbial community structure is linked to restoration activity, it is unclear if the alteration of the soil microbe community by an invasive plant can affect the 
vegetation restoration in the management and control practices. Therefore, our objective was to determine if modifying the soil microbial community with antimicrobial drugs was sufficient to initiate successful reestablishment of native species after $A$. adenophora removal. In addition, we investigated if other soil characteristics, including soil chemistry and soil enzymes, play a role in the recovery of plant communities.

\section{Materials and methods}

\section{Site description}

The experimental field site, located on Xishan mountain in Kunming, Yunnan, China $\left(24^{\circ} 58^{\prime} 24^{\prime \prime} \mathrm{N}, 102^{\circ} 37^{\prime} 17^{\prime \prime} \mathrm{E}\right.$; altitude $\left.2,214 \mathrm{~m}\right)$, has been heavily invaded (>90\% cover) by $A$. adenophora for at least 10 years. Climate data in this site were obtained from the WorldClim database using ArcGIS v10.3 (Yahdjian et al., 2011), with an annual mean temperature of $15.4^{\circ} \mathrm{C}$ and an annual precipitation of $1024 \mathrm{~mm}$. This site has experienced great changes in soil chemistry and in its soil microbial community since $A$. adenophora invasion (Xu et al., 2012), making it an ideal location for exploring soil priority effects on restoration.

\section{Modifications to soil microbe community}

Two plots, each $3 \mathrm{~m} \times 3 \mathrm{~m}$, were selected for manual removal of all A. adenophora individuals and other plant species. Each plot was subdivided into four $1 \mathrm{~m} \times 1 \mathrm{~m}$ blocks, each separated by $20 \mathrm{~cm}$. In June 2009, before the beginning of the rainy season, each block was randomly treated with one of three antimicrobial pesticides (Chlorothalonil (commercial name Baijunqing, BJQ), Carbendazim (commercial name Duojunling, DJL) or Streptomycin (commercial name Lianmeisu, LMS)) to inhibit soil microbes. BJQ is a broad-spectrum pesticide and inhibits both fungal and bacterial communities. DJL is also abroad-spectrum pesticide, but mainly inhibits the fungal community (Shao et al., 2011). LMS is used to treat soil-born bacterial pathogens. DJL, BJQ, and LMS were applied to the blocks at dosages of $31.96 \mathrm{~g} / \mathrm{m}^{2}, 21.76 \mathrm{~g} / \mathrm{m}^{2}$, and $28 \mathrm{~g} / \mathrm{m}^{2}$, respectively, inhibiting soil microbes at a depth of $20 \mathrm{~cm}$ (Shao et al., 2011). Because pesticide activity continuously diminishes in the soil after initial application, an additional three supplemental treatments were applied to the blocks in July, August, and September 2009. Blocks treated with sterilized water were used as control.

\section{Plant harvest and soil collection}

At the end of October 2009, 2010, and 2011, all plants $\geq 10 \mathrm{~cm}$ in height were identified and counted in $0.2 \mathrm{~m} \times 1 \mathrm{~m}$ subplots in each block (Fig. 1). Subsequently, each plant was cut down, placed into a paper bag, dried at $60{ }^{\circ} \mathrm{C}$ for $48 \mathrm{~h}$, and weighed. About one kilogram of soil was collected from the top $10 \mathrm{~cm}$ of soil in each subplot and analyzed for chemical composition and enzyme activity.

\section{Soil chemistry and enzyme analysis}

At the end of October 2009 and 2010, soil chemistry and enzyme were analyzed. In 2011, we only harvested plant materials for measurement but did not collect soils, therefore missing of the soil properties for the third year. Soil $\mathrm{pH}$, organic matter, and total and available $\mathrm{N}, \mathrm{P}$, and $\mathrm{K}$ in all soil samples were measured commercially (see 
Standard methods for observation and analysis in Chinese ecosystem research network, 1996). Briefly, soil pH was measured by the glass electrode method, after 2.5 -fold water extraction. Organic matter was determined using the oil bath- $\mathrm{K}_{2} \mathrm{CrO}_{7}$ titration method. Total $\mathrm{N}$ was assessed by the Kjeldahl method, and available $\mathrm{N}$ was determined by the Conway microdiffusion method. Total and available $\mathrm{P}$ were measured by $\mathrm{Mo}-\mathrm{Sb}$ colorimetric analysis. Total and available $\mathrm{K}$ were assessed with flame photometry.
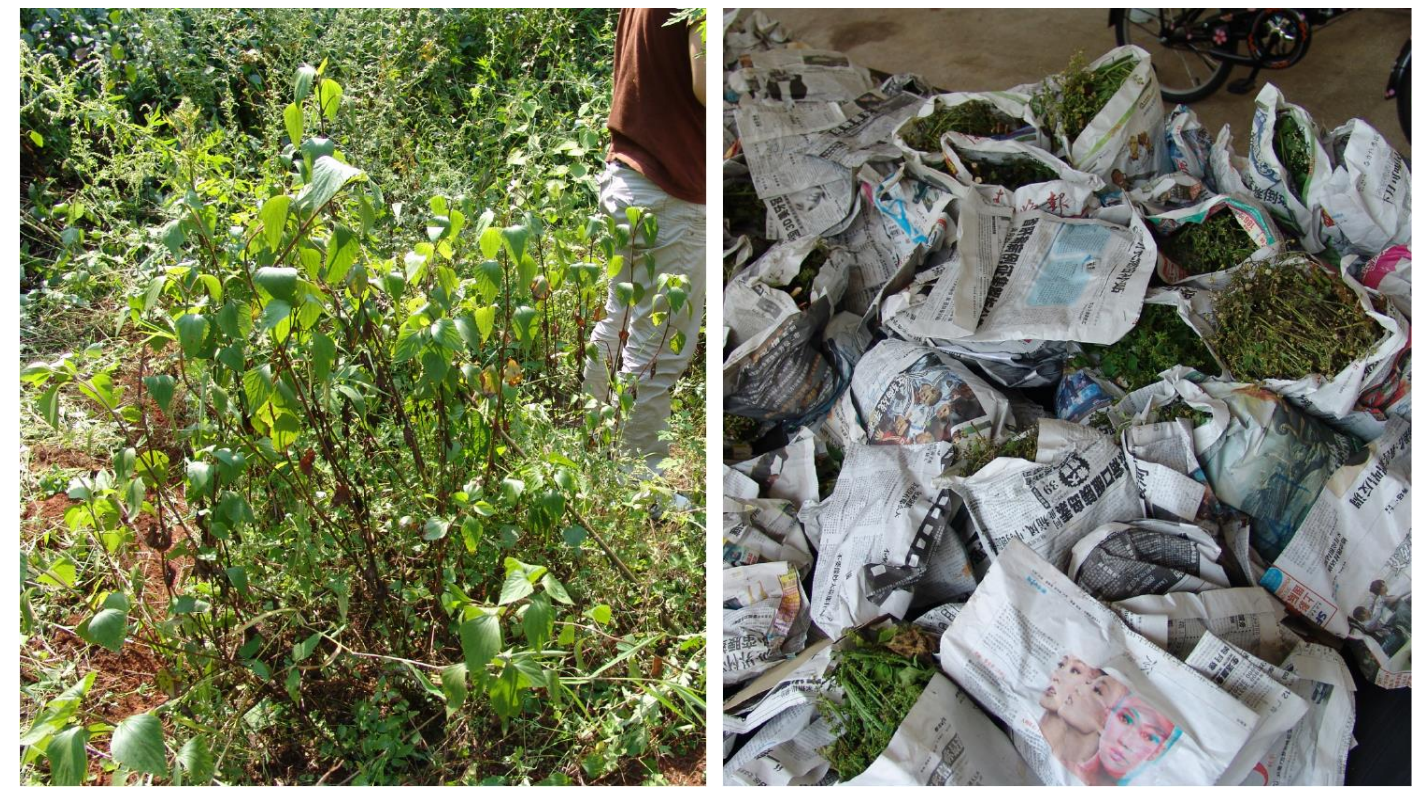

Figure 1. Experimental field (left) and plant harvest for measurement (right)

Soil enzyme activity was assayed in triplicate. For invertase activity, $5 \mathrm{~g}$ of air-dried soil was incubated for $24 \mathrm{~h}$ at $37^{\circ} \mathrm{C}$ with $15 \mathrm{~mL} 8 \%$ sucrose, $5 \mathrm{~mL}$ phosphate buffer at $\mathrm{pH} 5.5$, and $0.1 \mathrm{~mL}$ toluene. The glucose released by invertase reacted with 3-5dinitrosalicylic acid and 3-aminonitrosalicylic acid, which was then measured (as $\mathrm{mg}$ glucose released $\mathrm{g}^{-1}$ dry soil $24 \mathrm{~h}^{-1}$ ) at $508 \mathrm{~nm}$ (UV 330, Unicam UV-vis). For Caseinhydrolyzing protease activity, $5 \mathrm{~g}$ of air-dried soil was incubated for $48 \mathrm{~h}$ at $30{ }^{\circ} \mathrm{C}$ with $25 \mathrm{~mL} 1 \%$ casein and $1 \mathrm{~mL}$ toluene, followed by addition of $25 \mathrm{~mL}$ of $10 \%$ Trichloroacetic acid to halt the enzyme reaction. The amount of amino acids released was determined by the Folin colorimetric method at $680 \mathrm{~nm}$, measured as $\mathrm{mg}$ Tyrosine $\mathrm{g}^{-1}$ dry soil $48 \mathrm{~h}^{-1}$. For catalase activity, $2 \mathrm{~g}$ air-dried soil was mixed with $40 \mathrm{~mL}$ distilled water and $5 \mathrm{~mL} 0.3 \% \mathrm{H}_{2} \mathrm{O}_{2}$, shaken for $20 \mathrm{~min}$ at $120 \mathrm{r} / \mathrm{min}$, and the filtrate was titrated with $0.005 \mathrm{~mol} / \mathrm{L} \mathrm{KMnO}_{4}$. Catalase activity was expressed as $\mathrm{mL} 0.005 \mathrm{~mol} \mathrm{~L}^{-1} \mathrm{KMnO}_{4}$ $\mathrm{g}^{-1}$ dry soil $20 \mathrm{~min}^{-1}$. Soil polyphenol oxidase activity was measured by colorimetric method at $430 \mathrm{~nm}$, determined by purpurogallin formation in soil samples using the substrate pyrogallic acid after $3 \mathrm{~h}$ incubation at $30{ }^{\circ} \mathrm{C}$. Soil polyphenol oxidase activity was expressed as mg purpurogallin $100 \mathrm{~g}^{-1}$ dry soil $3 \mathrm{~h}^{-1}$ (Ma et al., 2003). Urease activity was determined by the modified colorimetric method (McGarity and Myers, 1967). Two milliliters of toluene was added to $20 \mathrm{~g}$ of soil and incubated for about $15 \mathrm{~min}$ to allow toluene to penetrate into the soil. Twenty milliliters of potassium citrate-citric acid buffer $(\mathrm{pH}$ 6.7) and $10 \mathrm{~mL}$ of $10 \%$ urea were then added and incubated for $3 \mathrm{~h}$ at $37{ }^{\circ} \mathrm{C}$. The amount of $\mathrm{NH}_{3}-\mathrm{N}$ released (expressed as $\mathrm{mg} \mathrm{NH}_{3}-\mathrm{N}$ $100 \mathrm{~g}^{-1}$ dry soil $3 \mathrm{~h}^{-1}$ ) was measured using Indophenol Blue Method at $578 \mathrm{~nm}$. 


\section{Data analysis}

The Shannon-Wiener index (H') was used to assess species diversity of the plant community (Spellerberg and Fedor, 2003). To account for the absence of A. adenophora in some subplots (recorded as zero), a value of one was added to all A. adenophora seedling records. Data were then transformed using a square root transformation for statistical analysis. The effects of each treatment on the plant community, soil chemistry, and soil enzymes were analyzed with a two-factor (year and drug) repeatedmeasures analysis of variance (ANOVA) to determine (1) whether these parameters changed over time and (2) whether drug treatments differed. Post hoc comparisons were made using least square differences (LSD). We reported F-tests adjusted for nonsphericity of the variance-covariance matrices using the Greenhouse-Geisser epsilon; hence some degrees of freedom were non-integer (Muller and Barton, 1989). All analyses were conducted in the SPSS software package (SPSS, Chicago, IL).

\section{Results}

\section{Effects of soil microbes on the restoration of native plant community}

The average biomass of individual $A$. adenophora, plant community diversity ( $\left.\mathrm{H}^{\prime}\right)$, total biomass including $A$. adenophora, and the biomass of other plant species significantly changed cross years (Table 1). Moreover, these traits linearly increased over the period of three years of experiment (The biomass of A. adenophora, $\mathrm{F}=19.478, \mathrm{p}=0.022$; plant community diversity, $\mathrm{F}=34.896, \mathrm{p}=0.010$; total biomass including A. adenophora, $\mathrm{F}=80.511, \mathrm{p}=0.003$; the biomass of other plant species, $\mathrm{F}=32.254, \mathrm{p}=0.011$ ) (Fig. 2). But there was no significant change of population density and total biomass of $A$. adenophora over time (Table 1 ).

Table 1. Repeated measures analysis of variance for plant community

\begin{tabular}{c|c|c|c|c|c|c|c|c|c}
\hline \multirow{2}{*}{ Source } & \multicolumn{3}{|c|}{ Year } & \multicolumn{3}{c|}{ Drug } & \multicolumn{3}{c}{ Year $\times$ drug } \\
\cline { 2 - 10 } & df & F & P & df & F & P & df & F & P \\
\hline Population density & 1.216 & 2.115 & 0.233 & 3 & 2.727 & 0.216 & 3.648 & 0.058 & 0.998 \\
Total biomass of A. adenophora & 1.096 & 3.251 & 0.162 & 3 & 15.909 & 0.024 & 3.287 & 0.696 & 0.620 \\
Average biomass of individual & 1.186 & 8.724 & 0.047 & 3 & 5.367 & 0.101 & 3.559 & 1.206 & 0.435 \\
A. adenophora & & & & & & & & & \\
Diversity (H') & 1.012 & 25.636 & 0.014 & 3 & 8.178 & 0.059 & 3.037 & 3.185 & 0.182 \\
Total biomass & 1.366 & 69.509 & 0.001 & 3 & 2.472 & 0.238 & 4.099 & 1.013 & 0.495 \\
Biomass of other plant species & 1.126 & 23.376 & 0.012 & 3 & 6.800 & 0.075 & 3.377 & 0.420 & 0.767 \\
\hline
\end{tabular}

Drug treatment had a negative, though not significant, effect on the population density of $A$. adenophora, and significantly decreased the total biomass of $A$. adenophora (Fig. 2A, D). Relative to the control, BJQ, DJL, and LMS decreased $A$. adenophora biomass by $46.73 \%, 70.69 \%$, and $96.95 \%$, respectively. Although drug treatment also decreased individual biomass of $A$. adenophora, only streptomycin (LMS) was statistically significant $(\mathrm{p}=0.029)$ (Fig. 2B). Interestingly, application of DJL $(\mathrm{p}=0.018)$ and LMS $(\mathrm{p}=0.038)$ significantly increased the biomass of other plant species by $68.5 \%$ and $43.87 \%$, respectively (Fig. $2 E$ ), as well as plant community diversity (Fig. 2C). 

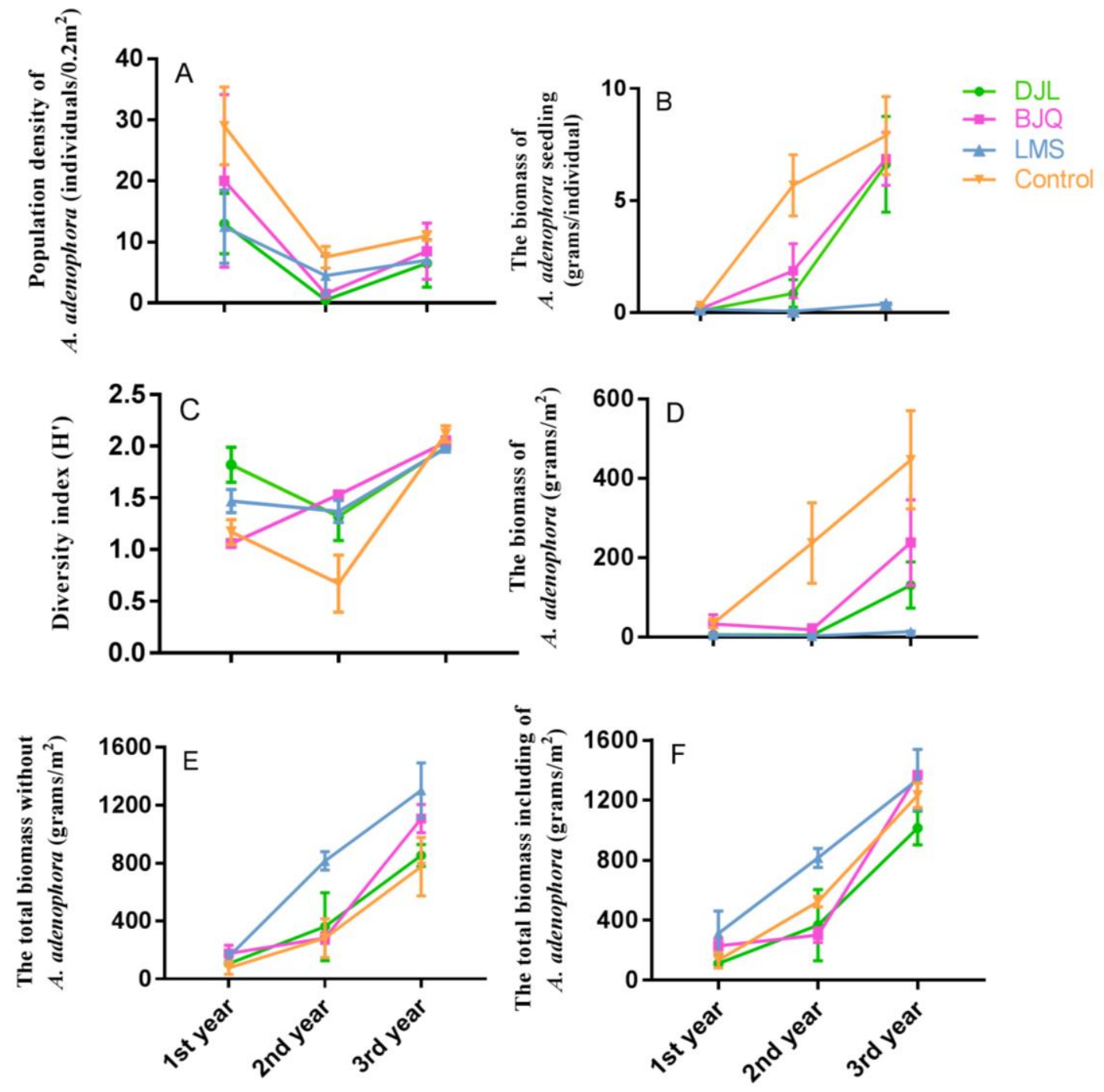

Figure 2. Effects of modifying soil microbe activity with antimicrobial treatments on plant community. DJL (Carbendazim) is a broad-spectrum pesticide, mainly affecting the fungal community; BJQ (Chlorothalonil) is a broad-spectrum pesticide and is able to inhibit both fungal and bacterial communities; LMS (Streptomycin) is used to treat soil-born bacterial pathogens. Control is represented with water treatment. Error bar represents one standard error

\section{Soil chemistry enzyme}

Only soil samples from 2009 and 2010 were analyzed. All chemistry characteristics significantly changed over years, except for total $\mathrm{P}(\mathrm{F}=2.778, \mathrm{p}=0.194)$ (Table 2; Fig. 3). Among of them, all pH values decreased from 2009 to 2010, while total K increased. Relative to the control, drug treatment changed most chemistry characteristics of soil, however, significant interactions were observed between treatment and year (Table 2). For example, three drugs significantly increased $\mathrm{pH}$ values at 2009 but decreased them at 2010; all drug treatments increased organic matter and total $\mathrm{N}$ at 2009 but decreased them at 2010 (Fig. 3). BJQ increased total P; LMS decreased available K at 2009 but increased it at 2010. DJL and BJQ increased available $\mathrm{N}$ and $\mathrm{P}$ at 2009 but decreased them at 2010. 

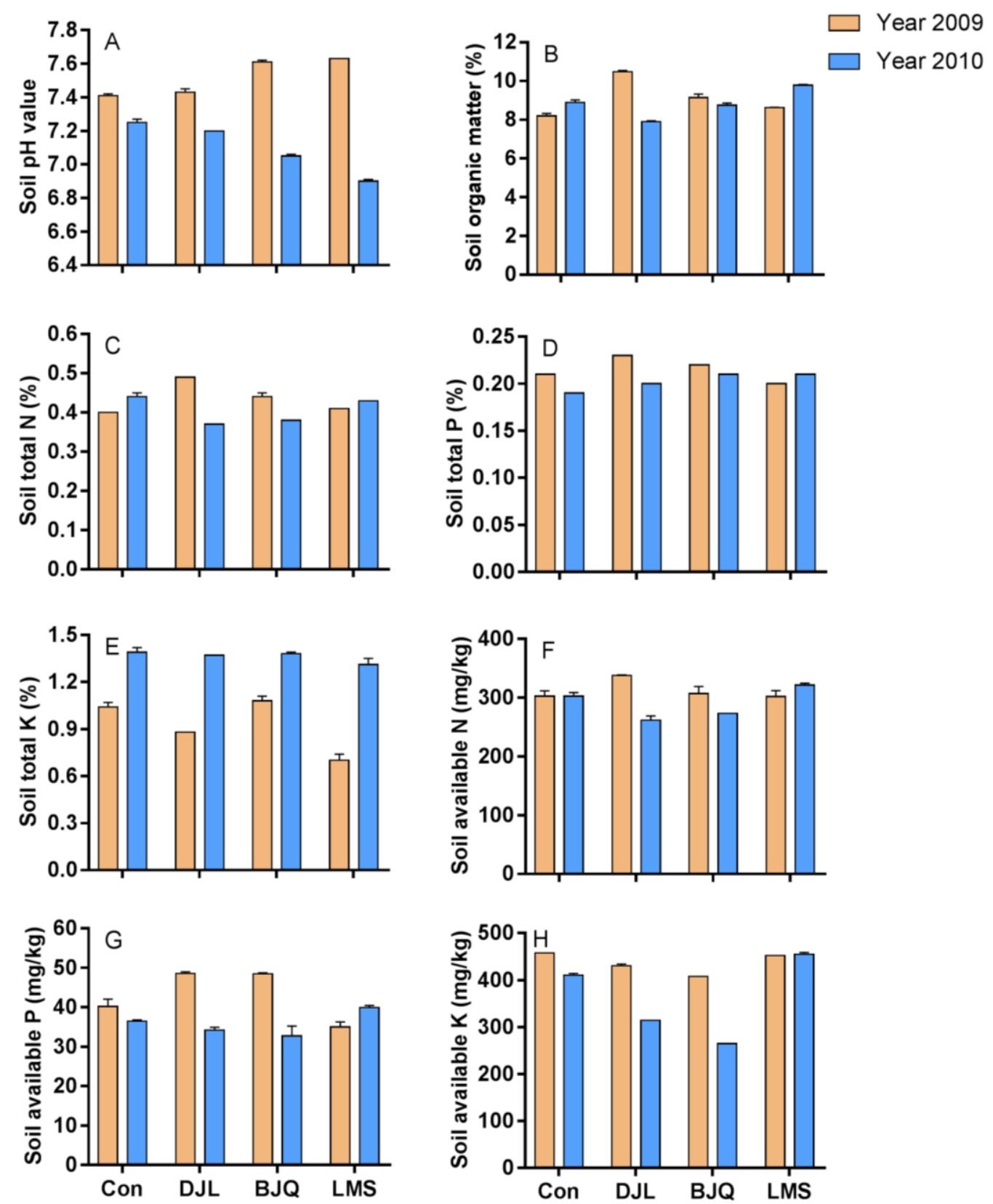

Figure 3. Effects of pesticide treatment on soil chemical characteristics. Con: control; DJL (Carbendazim) is a broad-spectrum pesticide, mainly affecting the fungal community; BJQ (Chlorothalonil) is a broad-spectrum pesticide and is able to inhibit both fungal and bacterial communities; LMS (Streptomycin) is used to treat soil-born bacterial pathogens. Error bar represents one standard deviation

From 2009 to 2010, soil protease activity significant increased, while the activity of catalase and polyphenol oxidase decreased over years, but urease and invertase had no changed (Table 2). Drug treatments significantly affected the activity of protease $(\mathrm{F}=30.182, \mathrm{p}=0.032)$, catalase $(\mathrm{F}=55.364, \mathrm{p}=0.018)$ and urease $(\mathrm{F}=28.358$, $\mathrm{p}=0.034)$. However, relative to the control, BJQ significantly decreased protease activity; BJQ and LMS significantly decreased catalase activity; and DJL significantly increased urease activity. 
Table 2. Repeated measures analysis of variance for soil chemistry and enzyme

\begin{tabular}{c|c|c|c|c|c|c|c|c|c}
\hline \multirow{2}{*}{ Source } & \multicolumn{3}{|c|}{ Year } & \multicolumn{5}{c|}{ Drug } & \multicolumn{3}{|c}{ Year $\times$ drug } \\
\cline { 2 - 9 } & df & F & P & df & F & P & df & F & P \\
\hline Soil enzyme & & & & & & & & & \\
Protease & 1 & 1227.458 & 0.001 & 3 & 30.182 & 0.032 & 3 & 27.017 & 0.036 \\
Polyphenol oxidase & 1 & 90.632 & 0.011 & 3 & 2.751 & 0.278 & 3 & 6.485 & 0.137 \\
Catalase & 1 & 2174.738 & 0.000 & 3 & 55.364 & 0.018 & 3 & 43.868 & 0.022 \\
Urease & 1 & 7.621 & 0.110 & 3 & 28.358 & 0.034 & 3 & 1.397 & 0.443 \\
Invertase & 1 & 18.580 & 0.050 & 3 & 3.538 & 0.228 & 3 & 7.230 & 0.124 \\
\hline Soil chemistry & & & & & & & & & \\
pH & 1 & 2048.000 & 0.000 & 3 & 421.000 & 0.000 & 3 & 151.000 & 0.001 \\
Organic matter & 1 & 4160.250 & 0.000 & 3 & 367.906 & 0.000 & 3 & 113.354 & 0.001 \\
Total N & 1 & 240.158 & 0.001 & 3 & 284.636 & 0.000 & 3 & 4.789 & 0.115 \\
Total P & 1 & 2.778 & 0.194 & 3 & 187.667 & 0.001 & 3 & 2.778 & 0.212 \\
Total K & 1 & 3264.000 & 0.000 & 3 & 106.022 & 0.002 & 3 & 142.235 & 0.001 \\
Available N & 1 & 101.999 & 0.002 & 3 & 123.741 & 0.001 & 3 & 9.293 & 0.050 \\
Available P & 1 & 1275.391 & 0.000 & 3 & 125.944 & 0.001 & 3 & 240.108 & 0.000 \\
Available K & 1 & 20557.989 & 0.000 & 3 & 1295.842 & 0.000 & 3 & 3877.301 & 0.000 \\
\hline
\end{tabular}

\section{Discussion}

Ecosystems disturbed by non-native plants are often unable to be restored. Such a situation often results from the impact of non-native plants on soil biogeochemical characteristics and microbial communities, with negative effects persisting even after the removal of non-native plants (Hamman et al., 2013). There are three mechanisms commonly proposed for explaining how non-native plants influence the restoration of native communities by altering soil properties: changes in resource availability, buildup of allelochemicals, and alterations of soil microbial communities (Grman and Suding, 2010).

In general, resource availability increases in soil after invasion of non-native plants (Blumenthal, 2006; Littschwager et al., 2010; Sharma et al.,2010). Because most invasive plant species are adapted to high resource availability, native plants tend to be at a disadvantage when they co-occur with non-native plants (Blumenthal, 2006). In contrast, a low supply of nutrients likely reduces the potential of invasive species to grow (Kueffer, 2010). Previous research suggested A. adenophora invasion tends to increase soil fertility (Liu et al., 2007; Niu et al., 2007; Sun et al., 2013). Here, drug treatment decreased the growth of A. adenophora (Fig. 2) and increased soil fertility at 2009 (Fig. 2), indicating that increased resource availability is not the major reason for the soil priority effects of $A$. adenophora.

Although $A$. adenophora generally consumes soil nutrients at a high rate, its invasion tends to increase soil fertility (Liu et al., 2007; Sun et al., 2013). Such a conflict fact was considered resulting from the changed soil microbial community (Niu et al., 2007), for example, increased soil nitrogen-fixing bacterial number after A. adenophora invasion may facilitate $A$. adenophora to obtain more nutrients from surrounding soil (Xu et al., 2012). The fact that drug treatment decreased most soil nutrients in 2010 thus suggested that soil microbes play an important role in maintaining the high requirements of the growth of $A$. adenophora. 
Interestingly, urease, protease, polyphenol oxidase, and peroxidase activity in plant communities that included A. adenophora were greater than that in any native grass community (Liu et al., 2007; Sun et al., 2013). In this case, BJQ significantly decreased protease activity, while BJQ and LMS significantly decreased peroxidase activity (Fig. 4). Consequently, modifying the soil microbe community with antimicrobial drug treatments will likely helpful to restore soil enzyme activity to normal levels.
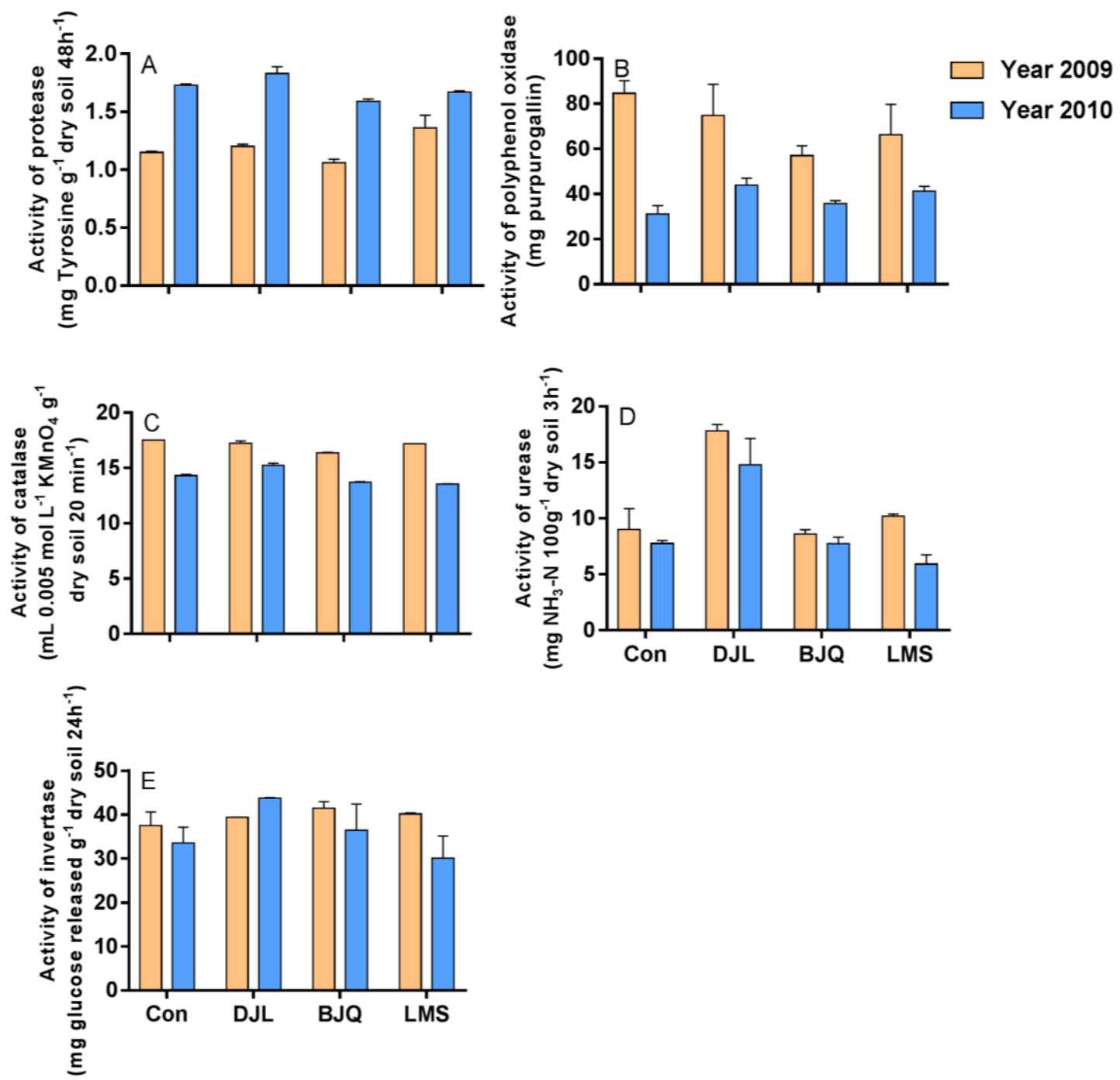

Figure 4. Effects of pesticide treatment on the activity of soil enzymes. Con, control; DJL (Carbendazim) is a broad-spectrum pesticide, mainly affecting the fungal community; BJQ (Chlorothalonil) is a broad-spectrum pesticide and is able to inhibit both fungal and bacterial communities; LMS (Streptomycin) is used to treat soil-born bacterial pathogens. Error bar represents one standard deviation

Allelochemical buildup in soil has been demonstrated to be important for the invasion of several plant species, including Alliaria petiolata (Bauer et al., 2010; Lankau, 2012) and Centaurea maculosa (Perry, 2005). However, the utilization of allelochemicals is also unlikely to be a key factor for the priority effects of $A$. adenophora. Although water extracts of A. adenophora leaves adversely affected the 
growth of some plant species (Zhong and Duan, 2006), allelochemicals were not found to persist in the soil after defoliation. Further, a greenhouse experiment also demonstrated that allelochemicals in soils of $A$. adenophora have little effect on native plants (Yu et al., 2005). More recently, A. adenophora has been verified to accumulate bacteria which can degrade the allelochemicals and thus decrease the allelopathic effects in soils (Li et al., 2017).

The invasion of $A$. adenophora strongly changes the soil microbial community, including both fungi and bacteria (Niu et al., 2007; Sun et al., 2013). For instance, Xu et al. (2012) found that A. adenophora accumulated a greater number and diversity of nitrogen-fixing bacteria than native plant species. In light of these studies, our results indicate that microbes may be the key factor inhibiting the growth of native plants after removal of $A$. adenophora. Moreover, LMS, which mainly inhibits soil bacterial growth, decreased $A$. adenophora biomass to the greatest degree, while DJL, which mainly inhibits soil fungal growth, increased the biomass of other plants the most (Fig. 2). This suggests that, if A. adenophora accumulates microbes beneficial for its own growth (Fig. 2, also see Yu et al., 2005; Niu et al., 2007), these microbes are likely to be bacteria, particularly nitrogen-fixing species (Xu et al., 2012; Zhao et al., 2019) or other selectively accumulated bacteria in roots (Chen et al., 2019). Therefore, the microbes inhibiting native plant growth are most likely pathogenic fungi. However, deciphering which group (or species) of fungi contributes to this inhibition depends on the comparison of the established microbial community by A. adenophora invasion with the changed one after the application of antimicrobial drugs, with the integration of the culture-dependent and culture-independent methods. It is too complex and beyond this study aim.

Although initial removal of non-native plants may be successful, reinvasion of nonnative plants from remnant seed banks can be challenging to control and hinders restoration of the ecosystem (Adams and Galatowitsch, 2006; Simberloff, 2013). Like most invasive plants, A. adenophora produces a vast amount of seeds, and its seed bank persists in the soil for several years (Shen and Liu, 2004). Therefore, modifying the community of soil microbes becomes important for the restoration of the degraded area by $A$. adenophora after eradication. Aside from microbes, soil fauna may affect aboveground vegetation (Sackett et al., 2010); however, we were unaware if there were any side effects on soil fauna from the pesticides used in our experiment. In addition, the impact of an invasive plant on an ecosystem can change over time. For example, native species richness and productivity were initially reduced by the invasive plant Heracleum mantegazzianum but tended to recover about 30 years after invasion (Dostál et al., 2013). Therefore, future studies may want to focus on whether the negative effects of soil microbes on ecosystem restoration decrease over the invasion history of A. adenophora.

\section{Conclusions}

In this study we indicated the effects of soil microbes on the restoration of native plant. Drug treatment had significantly decreased the total biomass of A. adenophora. Relative to the control, BJQ, DJL, and LMS decreased $A$. adenophora biomass by 46.73\%, 70.69\%, and 96.95\%, respectively. Meanwhile, application of DJL and LMS significantly increased the biomass of other native plant species, as well as plant community diversity. 
Chemistry characteristics, including $\mathrm{pH}, \mathrm{N}$ and $\mathrm{K}$, significantly changed over years, but total $\mathrm{P}$ had no changed. Relative to the control, drug treatment changed most chemistry characteristics of soil.

Soil protease activity significant increased, while the activity of catalase and polyphenol oxidase decreased over years, but urease and invertase had no changed. Drug treatments significantly affected the activity of protease, catalase and urease. Our data indicated that $A$. adenophora hinders the successful reestablishment of native species by changing the soil microbial community, and thus inhibiting the activity of soil microbes that promote non-native plant establishment and growth is beneficial for both eradication and replacement of $A$. adenophora.

Finally, although three chemical antimicrobial drugs we used in this study have been commonly applied in agricultural system for disease protection of crops (see materials and methods), the potential risk in natural ecosystems, e.g., carcinogenic and mutagenic effects, needs to be evaluated carefully in the case these drugs are utilized in the restoring vegetation degraded by invasive plants.

Acknowledgements. We thank Chen Yang, Zhen-Xin Zhou, Huan Jiang, Yun-Jiao Chen, and Li-Min Chen at Yunnan University for experimental assistance in the wild. This project was supported by the National Natural Science Foundation of China (Nos. 30960077, 31360153).

\section{REFERENCES}

[1] Adams, C. R., Galatowitsch, S. M. (2006): Increasing the effectiveness of reed canary grass (Phalaris arundinacea L.) control in wet meadow restorations. - Restoration Ecology 14: 441-451.

[2] Adler, P., D'Antonio, C. M., Tunison, J. T. (1998): Understory succession following a dieback of Myrica faya in Hawaii Volcanoes National Park. - Pacific Science 52: 69-78.

[3] Bauer, J. T., Anderson, R. C., Anderson, M. R. (2010): Competitive interactions among first-year and second-year plants of the invasive, biennial garlic mustard (Alliaria petiolata) and native ground layer vegetation. - Restoration Ecology 18: 720-728.

[4] Blumenthal, D. M. (2006): Interactions between resource availability and enemy release in plant invasion. - Ecology Letters 9: 887-895.

[5] Blumenthal, D. M., Mitchell, C. E., Pysek, P., Jarosik, V. (2009): Synergy between pathogen release and resource availability in plant invasion. - Proceedings of the National Academy of Sciences of the USA 106: 7899-7904.

[6] Callaway, R. M., Thelen, G., Rodriguez, A., Holben, W. E. (2004): Soil biota and exotic plant invasion. - Nature 427: 731-733.

[7] Chen, L., Fang, K., Zhou, J., Yang, Z. P., Dong, X. F., Dai, G. H., Zhang, H. B. (2019): Enrichment of soil rare bacteria in root by an invasive plant Ageratina adenophora. Science of the Total Environment 683: 202-209.

[8] Chen, S. G., Kang, Y., Zhang, M., Wang, X. X., Strasser, R. J., Zhou, B., Qiang, S. (2015): Differential sensitivity to the potential bioherbicide tenuazonic acid probed by the JIP-test based on fast chlorophyll fluorescence kinetics. - Environmental and Experimental Botany 112: 1-15.

[9] Dostál, P., Müllerová, J., Pyšek, P., Pergl, J., Klinerová, T. (2013): The impact of an invasive plant changes over time. - Ecology Letters 16: 1277-1284.

[10] Elgersma, K. J., Ehrenfeld, J. G., Yu, S., Vor, T. (2011): Legacy effects overwhelm the short-term effects of exotic plant invasion and restoration on soil microbial community structure, enzyme activities, and nitrogen cycling. - Oecologia 167: 733-745. 
[11] Elliott, D. R., Caporn, S. J. M., Nwaishi, F., Nilsson, R. H., Sen, R. (2015): Bacterial and fungal communities in a degraded ombrotrophic peatland undergoing natural and managed re-vegetation. - PloS One 10(5): 20.

[12] Eppinga, M. B., Rietkerk, M., Dekker, S. C., De Ruiter, P. C., Van der Putten, W. H. (2006): Accumulation of local pathogens: a new hypothesis to explain exotic plant invasions. - Oikos 114: 168-176.

[13] Feng, J., Zhu, Y. (2010): Alien invasive plants in China: risk assessment and spatial patterns. - Biodiversity and Conservation 19: 3489-3497.

[14] Feng, Y., Wang, J., Sang, W. (2007): Biomass allocation, morphology and photosynthesis of invasive and noninvasive exotic species grown at four irradiance levels. - Acta Oecologica 31: 40-47.

[15] Feng, Y., Lei, Y., Wang, R., Callaway, R. M., Valiente-Banuet, A., Inderjitd Lia, Y., Zheng, Y. (2009): Evolutionary tradeoffs for nitrogen allocation to photosynthesis versus cell walls in an invasive plant. - Proceedings of the National Academy of Sciences of the USA 106: 1853-1856.

[16] Grman, E., Suding, K. (2010): Within-year soil legacies contribute to strong priority effects of exotics on native California grassland communities. - Restoration Ecology 18: 664-670.

[17] Hamman, S. T., Hawkes, C. V. (2013): Biogeochemical and microbial legacies of nonnative grasses can affect restoration success. - Restoration Ecology 21: 58-66.

[18] Kardol, P., Wardle, D. A. (2010): How understanding aboveground-belowground linkages can assist restoration ecology. - Trends in Ecology and Evolution 25: 670-679.

[19] Klironomos, J. N. (2002): Feedback with soil biota contributes to plant rarity and invasiveness in communities. - Nature 417: 67-70.

[20] Kueffer, C. (2010): Reduced risk for positive soil-feedback on seedling regeneration by invasive trees on a very nutrient-poor soil in Seychelles. - Biological Invasions 12: 97 102.

[21] Lankau, R. A. (2011): Resistance and recovery of soil microbial communities in the face of Alliaria petiolata invasions. - New Phytologist 189: 536-548.

[22] Lankau, R. A. (2012): Interpopulation variation in allelopathic traits informs restoration of invaded landscapes. - Evolutionary Applications 5: 270-282.

[23] Li, Y. P., Feng, Y. L., Kang, Z. L., Zheng, Y. L., Zhang, J. L., Chen, Y. J. (2017): Changes in soil microbial communities due to biological invasions can reduce allelopathic effects. - Journal of Applied Ecology 54(5): 1281-1290.

[24] Littschwager, J., Lauerer, M., Blagodatskaya, E., Kuzyakov, Y. (2010): Nitrogen uptake and utilisation as a competition factor between invasive Duchesnea indica and native Fragaria vesca. - Plant and Soil 331: 105-114.

[25] Liu, C., Feng, Y., Tian, Y. (2007): Effects of Eupatorium adenophorum Sprengel invasion on soil enzyme activities and physical and chemical factors. - Bulletin of Botanical Research 27: 729-735.

[26] Ma, Y., Zhang, J. Y., Wong, M. H. (2003): Microbial activity during composting of anthracene-contaminated soil. - Chemosphere 52: 1505-1513.

[27] Mangla, S., Inderjit, Callaway, R. M. (2008): Exotic invasive plant accumulates native soil pathogens which inhibit native plants. - J Ecol 96: 58-67.

[28] Marchante, E., Kjøller, A., Struwe, S., Freitas, H. (2009): Soil recovery after removal of the $\mathrm{N}_{2}$-fixing invasive Acacia longifolia: consequences for ecosystem restoration. Biological Invasions 11: 813-823.

[29] McGarity, J. W., Myers, M. G. (1967): A survey of urease activity in soils of northern New South Wales. - Plant and Soil 27: 217-238.

[30] Muller, K. E., Barton, C. N. (1989): Approximate power for repeated-measures ANOVA lacking sphericity. - Journal of the American Statistical Association 84: 549-555. 
[31] Niu, H. B., Liu, W. X., Wan, F. H., Liu, B. (2007): An invasive aster (Ageratina adenophora) invades and dominates forest understories in China: altered soil microbial communities facilitate the invader and inhibit natives. - Plant and Soil 294: 73-85.

[32] Perry, L. G., Johnson, C., Alford, É. R., Vivanco, J. M., Paschke, M. W. (2005): Screening of grassland plants for restoration after spotted knapweed invasion. Restoration Ecology 13: 725-735.

[33] Reinhart, K. O., Royo, A. A., Van der Putten, W. H., Clay, K. (2005): Soil feedback and pathogen activity in Prunus serotina throughout its native range. - Journal of Ecology 93: 890-898.

[34] Richardson, D. M., Allsopp, N., D’Antonio, C. M., Milton, S. J., Rejmanek, M. (2000): Plant invasions: the role of mutualisms. - Biological Reviews 75: 65-93.

[35] Sackett, T. E., Classen, A. T., Sanders, N. J. (2010): Linking soil food web structure to above- and belowground ecosystem processes: a meta-analysis. - Oikos 119: 1984-1992.

[36] Sang, W., Zhu, L., Axmacher, J. C. (2010): Invasion pattern of Eupatorium adenophorum Spreng in southern China. - Biological Invasions 12: 1721-1730.

[37] Shao, Y., Wang, Z., Zou, L., Wu, S. (2011): Effect of chlorothalonil on soil microbial communities of Larix artificial shelter-forest. - Acta Ecologica Sinica 31: 819-829.

[38] Sharma, G. P., Muhl, S. A., Esler, K. J., Milton, S. J. (2010): Competitive interactions between the alien invasive annual grass Avena fatua and indigenous herbaceous plants in South African Renosterveld: the role of nitrogen enrichment. - Biological Invasions 12: 3371-3378.

[39] Shen, Y., Liu, W. (2004): Persistent soil seed bank of Eupatorium adenophora. - Acta Phytoecologica Sinica 28: 768-772.

[40] Simberloff, D., Martin, J., Genovesi, P., et al. (2013): Impacts of biological invasions: what's what and the way forward. - Trends in Ecology and Evolution 28: 58-66.

[41] Spellerberg, I. F., Fedor, P. J. (2003): A tribute to clarde Shannon (1916-2001) and a plea for more rigorous use of species richness, species diversity and the 'Shannon-Wiener' index. - Global Ecology and Biogeography 12: 177-179.

[42] Sun, X., Gao, C., Guo, L. (2013): Changes in soil microbial community and enzyme activity along an exotic plant Eupatorium adenophorum invasion in a Chinese secondary forest. - Chinese Science Bulletin 58: 4101-4108.

[43] Vogelsang, K. M., Bever, J. D. (2009): Mycorrhizal densities decline in association with nonnative plants and contribute to plant invasion. - Ecology 90: 399-407.

[44] Wang, C., Lin, H. L., Feng, Q. S., Jin, C. Y., Cao, A. C., He, L. (2017): A new strategy for the prevention and control of Eupatorium adenophorum under climate change in China. - Sustainability 9(11): 11.

[45] Wang, H., Xie, M., Zhang, G. (2008): Investigation and study on using plants to control Eupatorium adenophorum. - Forest Inventory and Planning 33: 108-111.

[46] Wang, R., Wang, J., Qiu, Z., Meng, B., Wan, F., Wang, Y. (2011): Multiple mechanisms underlie rapid expansion of an invasive alien plant. - New Phytologist 191: 828-839.

[47] Wang, R., Wang, Y. (2006): Invasion dynamics and potential spread of the invasive alien plant species Ageratina adenophora (Asteraceae) in China. - Diversity and Distributions 12: 397-408.

[48] Xu, C., Yang, M., Chen, Y., Chen, L., Zhang, D., Mei, L., Shi, Y., Zhang, H. (2012): Changes in non-symbiotic nitrogen-fixing bacteria inhabiting rhizosphere soils of an invasive plant Ageratina adenophora. - Applied Soil Ecology 54: 32-38.

[49] Yahdjian, L., Gherardi, L. A., Sala, O. E. (2011): Nitrogen limitation in arid-subhumid ecosystems: a meta-analysis of fertilization studies. - Journal of Arid Environments 75(8): 675-680.

[50] Yu, X. J., Yu, D., Lu, Z. J., Ma, K. P. (2005): A new mechanism of invader success: exotic plant inhibits natural vegetation restoration by changing soil microbe community. - Chinese Science Bulletin 50: 1105-1112. 
[51] Zhao, M. X., Lu, X. F., Zhao, H. X., Yang, Y. F., Hale, L., Gao, Q., et al. (2019): Ageratina adenophora invasions are associated with microbially mediated differences in biogeochemical cycles. - Science of the Total Environment 677: 47-56.

[52] Zhong, S., Duan, X. (2006): Allelopathic effects of Eupatorium adenophorum Spreng on germination of two pastures. - Seed 25: 18-20. 